\begin{tabular}{|c|c|c|}
\hline PORT SAID ENGINEERING RESEARCH JOURNAL \\
Faculty of Engineering - Port Said University \\
Volume 16 No. 1 pp: $126: 136$
\end{tabular}

\title{
Studying the Effect of Core Clay on Seepage
}

\author{
M. El Gendy ${ }^{1}$, Ahmed H. Merdan ${ }^{2}$, Mohamed Galal El Tarabily ${ }^{3}$
}

\section{ABSTRACT}

The seepage problems from open channels constitute one of the major problems facing ministry of water recourses and irrigation. Many solutions are suggested to solve the problem of seepage from channels, some solution by covering the bottom of the channel with concrete or asphalt, other solution by the use of sheet piles. The current study aims to control the seepage losses by using clay core to decrease the seepage amount. The clay core can decrease the seepage rate by increasing the length of seepage line. Since the seepage lines are inclined, the most effective position of clay core has been determined by studying the effect of vertical clay core with different penetration depths in the soil and different head difference. Similarly studying the seepage rate for different positions of the core clay and constant pressure difference $(\Delta H)$ has been evaluated.

Keywords: Seepage, Clay core, Seepage Problems, Sand Tank Model, Seepage Controlling.

\section{INTRODUCTION}

(1) The movement of water through soil under natural conditions is very complex and can be reproduced in full in laboratory. This complexity is caused by non-uniformity of natural soils over large areas, the stratified and the tectonic structures of geological layers, and by the fact that water movement in nature is generally three dimensional $[11,6]$.

Natural seepage from the canal depends on a number of parameters; these parameters are the wetted perimeter, hydraulic conductivity and the head losses across the seepage surface determined by the difference between the water level in the canal and the point out side the canal Ihssan et al (2007)

In the laboratory we have the advantage to being able to use homogeneous materials of known properties. This simplifies the problem and makes it possible to reduce the number of components involved, by this mean significant relationships between the physical properties of the medium and characteristics of flow are found. To further simplify the problem, we usually restrict ourselves to a two dimensional flow.

A washed, narrow range sand (coarse sand) with no significant fraction finer than $0.5 \mathrm{~mm}$ has been used. The sand was placed in the tank after the tank has been filled with water to ensure better spreading and mixing $[1,11]$.

Seepage underneath a clay wall is one of the seepage problems that are most common in practice. Clay walls are used to reduce seepage under all types of

1 Prof. of geotechnical and foundation engineering civil Eng. Dept., Faculty of Engineering Port Said University.

2 Lecturer .Civil Eng. Dept., Faculty of Engineering Port Said University.

${ }^{3}$ M. Sc Civil Engineering Department, Faculty of Engineering, Port Said University, Port Said, Egypt dams, lock walls, dividing walls, coffer-dams and similar structures, they are also used to reduce leakage from canals, rivers and sub-soils surrounding an excavation. To study this case and to study the effect of the clay core on reducing the rate of seepage, the sand tank model has been designed. The flow is considered to be evenly distributed with depth below the water table.

In comparing seepage rate based on the DupuitForchheimer theory with solution obtained with an electrical resistance net work analogy which takes vertical flow components into account, Bouwer found that the Dupuit theory gave reasonably accurate seepage values if the distance of the impermeable layer below the stream bottom was not more than twice the width of the water depth in the stream.

(2) The seepage rate depends on several factors, such as the geometry of the stream, the hydraulic conductivity $(\mathrm{K})$ and the difference between surface water level and ground level $(\Delta \mathrm{H})$.

The type of soil below the channel is widely affecting the seepage rate, as the permeability of the soil (the coefficient of permeability or hydraulic conductivity) which is being determined in the study along with the description of the seepage lines and their directions from open channel.[11,3]

The velocity of any moving water is related directly to the difference in the head between two points. Hence, the seepage rate will increase as $(\Delta \mathrm{H})$ increases.

Any seepage problems must consider three principal factors, which are soil media, type of flow, and boundary conditions. The soil media are important in the determination of seepage characteristics since different soil media will exhibit different behavior. Some of the most important characteristics that need to 
be determined from the soil media are transmissivity and coefficient of hydraulic conductivity.

Soil media can be classified by these different characteristics. For example, if the coefficient of permeability is the same at all points in the flow region and it is independent of the direction of the flow, the soil is classified as homogeneous and isotropic. If on the other hand it is dependent on the direction of the flow, it is classified as heterogeneous and isotropic. For soil that is only independent on the direction of the flow, it is classified as homogeneous and anisotropic.

The type of flow can be classified as either steady state or transient flow. In a steady state type of flow, time is not considered as a variable and the position of the water table does not change. On the other hand, a transient problem requires time as a variable and so an initial condition needs to be described aside from boundary conditions and a time step needs to be determined to correctly illustrate the influence of time on the problem (Affuso at al 2000).

Boundary conditions are also needed to correctly describe the problem. In flow domains where all the boundaries are fixed and therefore known initially, the flow is said to be confined, but where one boundary is a free surface, the flow pattern is said to be unconfined.

(3) The natural velocities of the groundwater flow and the seepage velocity are very small. They may be in range as low as $0.04 \mathrm{~m} /$ day in fine soils and higher values up to $30 \mathrm{~m} /$ day in coarse soils. Higher groundwater velocities are encountered as a result of artificial disturbance such as those zone in the immediate vicinity to open channels or pumped well, and also those zones which contains large diameter voids, where the flow no longer laminar due to steep hydraulic gradients (Bear 1990, Driscoll 1986 [10]).

(4) Seepage theory; the general case of seepage in two dimensions will now be considered. Initially it will be assumed that the soil is homogeneous and isotropic with respect to permeability, the coefficient of hydraulic conductivity being $\mathrm{k}$. In the $\mathrm{x}-\mathrm{z}$ plane, Darcy's law can be written in the generalized form with unit width:

$$
\begin{aligned}
& \mathrm{v}_{\mathrm{x}}=\mathrm{ki}_{\mathrm{x}}=-\mathrm{k} \frac{\partial \mathrm{h}}{\partial \mathrm{x}} \\
& \mathrm{v}_{\mathrm{z}}=\mathrm{ki}_{\mathrm{z}}=-\mathrm{k} \frac{\partial \mathrm{h}}{\partial \mathrm{z}}
\end{aligned}
$$

With the total head $h$ decreasing in the directions of $v_{x}$ and $v_{z}$. An element of fully saturated soil having dimensions $\mathrm{dx}, \mathrm{dy}$ and $\mathrm{dz}$ in the $\mathrm{x}, \mathrm{y}$ and $\mathrm{z}$ directions, respectively, with flow taking place in the $\mathrm{x}-\mathrm{z}$ plan only, is shown in Figure I. The components of discharge velocity of water entering the element are $v_{x}$ and $\mathrm{v}_{\mathrm{z}}$, and the rates of change of discharge velocity in the $\mathrm{x}$ and $\mathrm{z}$ directions are $\partial \mathrm{v}_{\mathrm{x}} / \partial_{\mathrm{x}}$ and $\partial \mathrm{v}_{\mathrm{z}} / \partial_{\mathrm{z}}$ respectively.

The volume of water entering the element per unit time is:

$$
v_{x} d_{z}+v_{z} d_{x}
$$

and the volume of water leaving per unit time is:

$$
\left(v_{\mathrm{x}}+\frac{\partial v_{\mathrm{x}}}{\partial \mathrm{x}} \mathrm{d}_{\mathrm{x}}\right) d_{z}+\left(v_{z}+\frac{\partial v_{z}}{\partial z} d_{z}\right) d_{x}
$$

If the element is undergoing no volume change and if water is assumed to be incompressible, the difference between the volume of water entering the element per unit time and the volume leaving must be zero. Therefore:

$$
\frac{\partial v_{\mathrm{x}}}{\partial \mathrm{x}}+\frac{\partial v_{\mathrm{z}}}{\partial \mathrm{z}}=0
$$

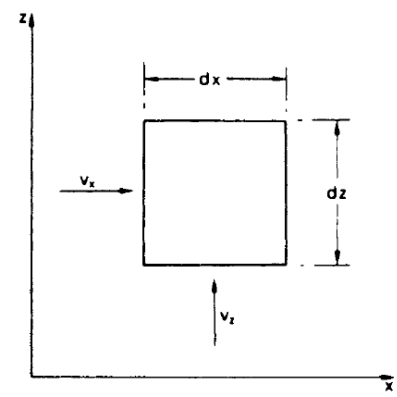

Figure I: Seepage through a soil element.

The main objectives of this study were: (1) Using sand tank model to simulate seepage flow through porous media; (2) Determine the flow net for different alternative for clay core, seepage rate and verification of Darcy's law; and (3) Comparison of experimental results with $(\mathrm{SEEP} / \mathrm{W})$ program.

\section{EXPERIMENTAL SETUP}

Drainage and seepage tank

\subsection{Theory:}

Sand tank model is a physical scale of ground flow of water by which some studies can be carried for water flow in permeable media. For example, the seepage rate can be determined for a channel in the field by making a model in the tank and studying the seepage for this model and determine the flow rate from:

$$
\mathrm{Q}_{\mathrm{m}}=\mathrm{K}_{\mathrm{m}} \cdot \mathrm{A}_{\mathrm{m}} \cdot\left(\Delta H_{\mathrm{m}} / L_{\mathrm{m}}\right)
$$

Where:

$\mathrm{Q}_{\mathrm{m}}=$ flow in model.

$\mathrm{K}_{\mathrm{m}}=$ hydraulic conductivity of sand in model.

$\mathrm{A}_{\mathrm{m}}=$ effective cross-sectional area of the flow.

$\Delta \mathrm{H}_{\mathrm{m}}=$ head difference in model.

$\mathrm{L}_{\mathrm{m}}=$ effective flow length in model.

The flow rate in the field (prototype) is:

$$
\mathrm{Q}_{p}=\mathrm{K}_{p} \cdot \mathrm{A}_{p} \cdot\left(\Delta H_{p} / L_{p}\right)
$$

Where: 
$\mathrm{Q}_{\mathrm{p}}=$ flow in prototype.

$\mathrm{K}_{\mathrm{p}}=$ hydraulic conductivity of sand in prototype.

$A_{p}=$ effective cross-sectional area of the flow.

$\Delta \mathrm{H}_{\mathrm{p}}=$ head difference in prototype.

$\mathrm{L}_{\mathrm{p}}=$ effective flow length in prototype.

Therefore the flow rate can be written in the form:

$$
Q_{p}=Q_{m} \cdot\left(K_{p} / K_{m}\right) \cdot\left(A_{p} / A_{m}\right) \cdot\left(\Delta H_{p} / \Delta H_{m}\right) \cdot\left(L_{m} / L_{p}\right)
$$

In order to test the effectiveness of clay core, it was necessary to construct a model to simulate the drainage patterns that occur in the soil mass. A constant head of water level was required for the upper boundary to simulate the saturated soil conditions.
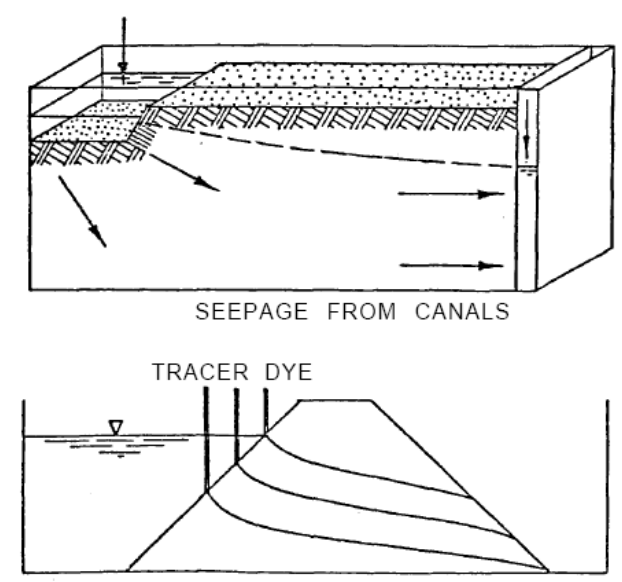

SEEPAGE IN EMBANKMENTS

Figure 1: sand tank model

Because flows in both model and prototype are occurring in porous media, kinematic and dynamic similarity is obtained. Geometric similarity is defined by the model-prototype length ratio:

$$
L_{r}=\frac{L_{m}}{L_{p}}
$$

Where the subscripts $\mathrm{r}, \mathrm{m}$, and $\mathrm{p}$ refer to ratio, model, and prototype, respectively. Because Darcy's law applies to both model and prototype, the velocity ratio:

$$
V_{r}=\frac{V_{m}}{V_{p}}=\frac{K_{m}}{\mathrm{~K}_{\mathrm{p}}} \frac{I_{m}}{\mathrm{I}_{\mathrm{p}}}
$$

Where $\mathrm{K}$ is the coefficient of hydraulic conductivity and $\mathrm{I}$ is the hydraulic gradient with similar slopes, the prototype velocity is given by:

$$
V_{p}=\frac{V_{m}}{K_{r}}
$$

And the flow rate by:

$$
Q_{\mathrm{p}}=\frac{\mathrm{Q}_{\mathrm{m}}}{\mathrm{K}_{\mathrm{r}} * \mathrm{~L}_{\mathrm{r}} 2}
$$

Soil consists of many individual grains of varying size, because the individual grains that make up soil do not fit tightly together, voids form between the grains. These voids act as a semi-continuous conduit for the flow of water.

Flow through these void spaces is called flow through porous media. One of the major destabilizing forces resulting in slope instability is the flow of water in porous media. As water or any fluid flows through soil, it exerts a force on the soil particles through friction (Cedergren, 1977 [5,9]).

The Flow of water through porous media is dependent on the following influencing variables:

*Cross-section of flow

*Permeability coefficient

*Slope

*Length of the path of flow.

The Flow is expressed mathematically as follows:

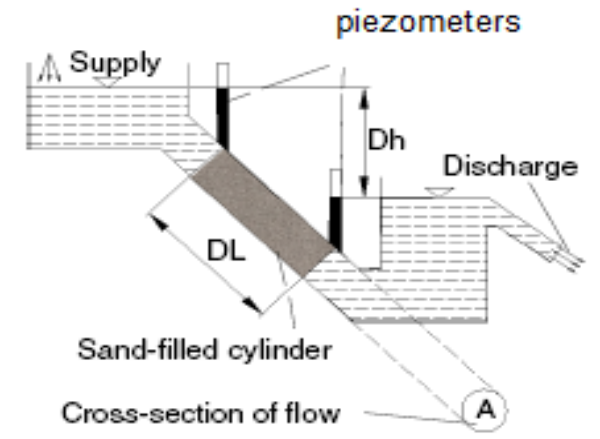

Flow through permeable media

$\mathrm{Q}$ : Flow in $\mathrm{m} 3 / \mathrm{h}$

$$
\mathrm{Q}=\mathrm{A} \cdot \mathrm{K} \cdot \frac{\Delta \mathrm{h}}{\Delta \mathrm{L}}
$$

A: Cross-section in $\mathrm{m} 2$

$\mathrm{K}$ : Permeability coefficient in $\mathrm{m} 3 /(\mathrm{m} 2 \mathrm{~h})$

$\Delta \mathrm{H}$ : Slope in $\mathrm{m}$

$\Delta \mathrm{L}$ : Length of path of flow in $\mathrm{m}$

The coefficient of hydraulic conductivity is dependent on the type of sand used.

\subsection{Description of apparatus}

The equipment is shown in figure2; with major dimensions in $\mathrm{mm}$. a specially designed stand supports the drainage and seepage tank has a mild steel "U" shaped frame, four sides toughened glass, two independent adjustable over flow, impermeable membrane at downstream side to allow water to flow from media without sand. 


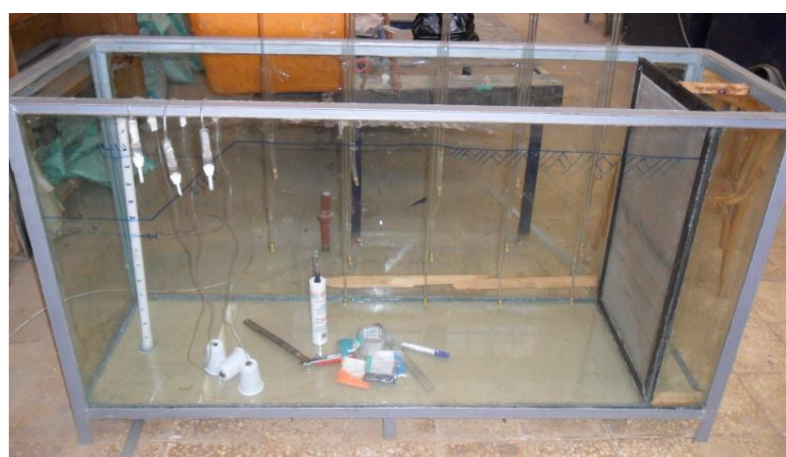

Figure 2: description of apparatus

\subsection{Seepage from open channel and flow lines}

If there is a difference between surface water level and groundwater level, the water will seep from the surface water to the groundwater which results in losing the surface water. To find the rate of seepage from the open channel, a section of one unit of stream is taken and Darcy's law is applied:

$$
\mathrm{Q}=\mathrm{A} \cdot \mathrm{K} \cdot \frac{\Delta \mathrm{h}}{\Delta \mathrm{L}}
$$

The flow lines are taken inclined shape. The water table is limited by the flow line that starts from the top of surface water to the top of groundwater. The flow lines are the shortest and fastest paths of the surface water to reach the groundwater. In these lines are longer, the seepage rate will decrease $[4,8]$.

Piezometric surveys: observation of water levels in a series of piezometers tubes located at a right angle to the center line of a canal provides data to determine the flow lines and equipotential lines of seepage water. The amount of seepage can then be calculated when the hydraulic conductivity of the soil is determined [10].

Drainage \& Seepage Tank is used to illustrate twodimensional flow through permeable substances. Different models can be placed in the transparent work area [14]. The transparent front panel of the work area is ideal for viewing the streamlines that are produced. The pressure distribution can also be determined via the (9) pressure measuring points and manometer board.

\subsection{Measurement of Hydraulic Conductivity (K)}

Hydraulic conductivity $(\mathrm{K})$ is a measurement of the permeability of some media, by using the sand tank model, one can determine the value of $(\mathrm{K})$ for the usable sand, this can be made by measuring seepage rate $(\mathrm{Q})$ for different head difference $(\Delta \mathrm{H})$ and applying Darcy's law to calculate $(K)$ for every $(\Delta H)$, then finding average $(\mathrm{K})$.

Figure 3: show all dimensions needed.
All calculations are based on a unit width which

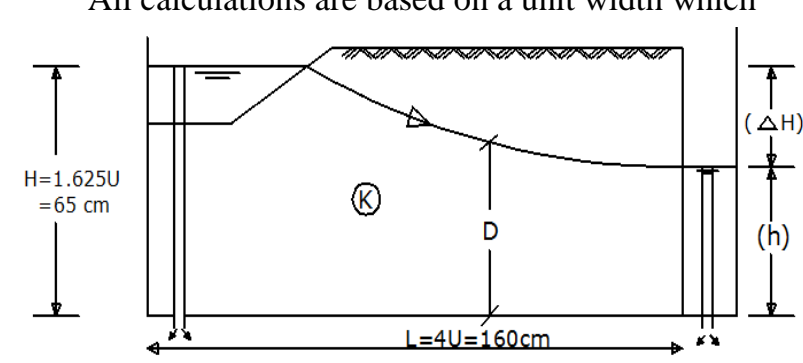

is equal to $40 \mathrm{~cm}$, in our model all dimensions are expressed in width(U) which equals to $40 \mathrm{~cm}$, and setting $\mathrm{H}=1.625 \mathrm{U}=65 \mathrm{~cm}$. Experiments were done three times with variable head difference $(\Delta \mathrm{H})$ equals $15 \mathrm{~cm}, 25 \mathrm{~cm}, 35 \mathrm{~cm}$. which expressed with $0.375 \mathrm{U}$, $0.625 \mathrm{U}, 0.875 \mathrm{U}$ For the three runs the volume of the exerted water was measured in a specific time so the discharge was calculated, from the dimensions of the apparatus we calculated the coefficient of hydraulic conductivity $(\mathrm{K})$.

For $\Delta H=0.375 U=15 \mathrm{~cm}$

Q1=80mililiter/0.5minute Q1=160mililiter/minute

Q1=240mililiter/1.5minute

Then the Q1avg. $=160 \mathrm{~mm} / \mathrm{min}=2.667 \mathrm{cc} / \mathrm{sec}$

For $\Delta H=0.625 U=25 \mathrm{~cm}$

Q2=120mililiter/0.5minute Q2=240mililiter/minute Q2=360mililiter/1.5minute

Then the Q2avg. = $240 \mathrm{~mm} / \mathrm{min}=4 \mathrm{cc} / \mathrm{sec}$

For $\Delta H=0.875 U=15 \mathrm{~cm}$

Q3=160mililiter/0.5minute $\mathrm{Q} 3=325 \mathrm{mililiter} /$ minute Q3=490mililiter/1.5minute

Then the Q1avg. $=325 \mathrm{~mm} / \mathrm{min}=5.417 \mathrm{cc} / \mathrm{sec}$

Table 1: values of Q (cc/sec) and $\mathrm{K}(\mathrm{cm} / \mathrm{sec})$

\begin{tabular}{|c|c|c|c|c|}
\hline $\mathbf{h}(\mathbf{U})$ & $\mathbf{\Delta H}(\mathbf{U})$ & $\mathbf{D}(\mathbf{U})$ & $\mathbf{Q}(\mathbf{c c} / \mathbf{s})$ & $\mathbf{K}(\mathbf{c m} / \mathbf{s})$ \\
\hline 1.25 & 0.375 & 1.4375 & 2.67 & 0.198 \\
1.0 & 0.625 & 1.3125 & 4.00 & 0.195 \\
0.75 & 0.875 & 1.1875 & 5.42 & 0.208 \\
\hline
\end{tabular}

Width $(\mathrm{W})=\mathrm{U}, \quad$ average depth $(\mathrm{D})=(\mathrm{H}+\mathrm{h}) / 2$ , hydraulic conductivity $(\mathrm{K})=(\mathrm{Q} . \mathrm{L}) /($ W. D. $\Delta \mathrm{H})$ 


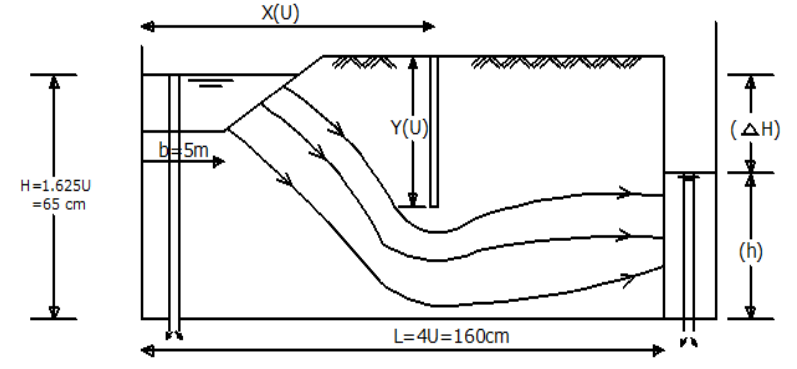

Figure 4: shows clay wall position $(\mathrm{X}), \operatorname{depth}(\mathrm{Y})$ and head difference $(\Delta \mathrm{H})$.

$$
\begin{gathered}
\mathrm{K} 1=(2.67 * 4) /(1 * 1.4375 * 0.375) \\
\mathrm{K} 1=0.198 \mathrm{~cm} / \mathrm{sec} \\
\mathrm{K} 2=(4 * 4) /(1 * 1.3125 * 0.625) \\
\mathrm{K} 2=0.195 \mathrm{~cm} / \mathrm{sec} \\
\mathrm{K} 3=(5.42 * 4) /(1 * 1.1875 * 0.875) \\
\mathrm{K} 3=0.208 \mathrm{~cm} / \mathrm{sec}
\end{gathered}
$$

\section{Average $k=0.2003 \mathrm{~cm} / \mathrm{sec}$}

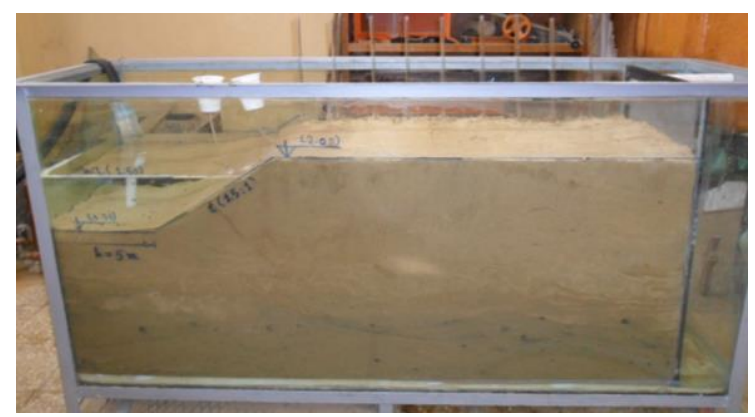

Figure 5: Filling with sand at the beginning of the experiment

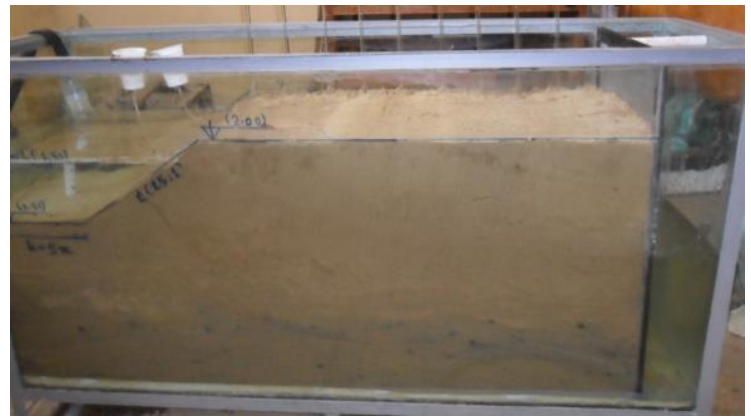

Figure 5': water reaches the highest level at down stream of $(\mathrm{h})=50 \mathrm{~cm}$, head difference $(\Delta \mathrm{H})=15 \mathrm{~cm}$.

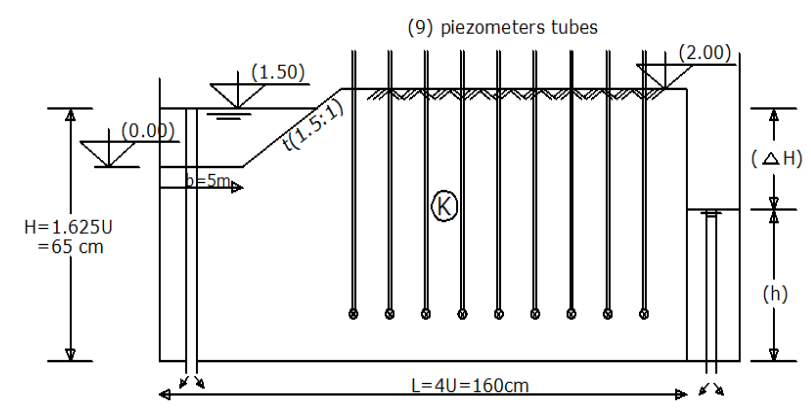

Figure 6: shows piezometers positions

\section{EFFECT OF CLAY WALL IN REDUCING SEEPAGE}

On of the solution to reduce seepage rate is the use of clay walls. To study the effect of clay wall for different head difference $(\Delta \mathrm{H})$ and for different $\operatorname{depth}(\mathrm{Y})$ and distance of the clay wall from channel(X), the experiment is being carried out with the following arrangement.

\subsection{Clay wall@ $\mathrm{X}=0.375 \mathrm{U}=15 \mathrm{~cm}, \mathrm{Y}=0.375 \mathrm{U}=15 \mathrm{~cm}$.}

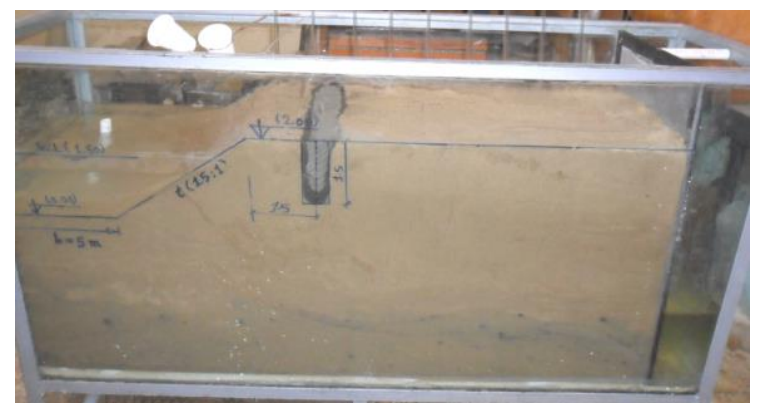

Figure 7: clay wall with depth $=0.375 \mathrm{U}$ and distance from canal $=0.375 \mathrm{U}$

Table 2: values of $\mathrm{Q}(\mathrm{cc} / \mathrm{sec})$ case (1)

\begin{tabular}{|l|l|}
\hline$\Delta \mathrm{H}=0.375 \mathrm{U}=15 \mathrm{~cm}$ & $\mathrm{Q}=155$ (cc/min.) \\
\hline$\Delta \mathrm{H}=0.625 \mathrm{U}=25 \mathrm{~cm}$ & $\mathrm{Q}=237$ (cc/min.) \\
\hline$\Delta \mathrm{H}=0.875 \mathrm{U}=35 \mathrm{~cm}$ & $\mathrm{Q}=325$ (cc/min.) \\
\hline
\end{tabular}

\subsection{Clay wall@ $\mathrm{X}=0.375 \mathrm{U}=15 \mathrm{~cm}, \mathrm{Y}=0.75 \mathrm{U}=30 \mathrm{~cm}$.}

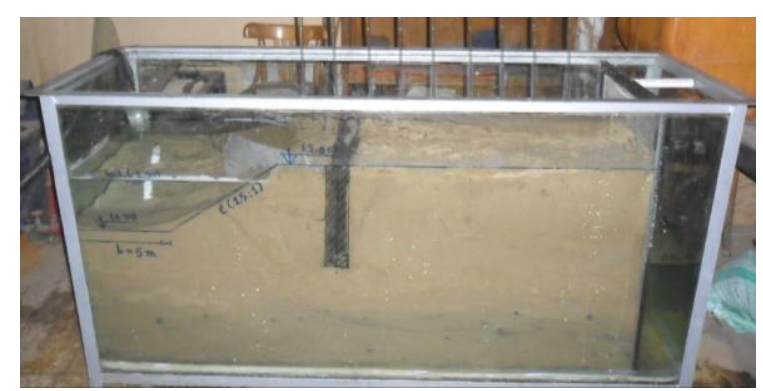

Figure 8: clay wall with depth $=0.75 \mathrm{U}$ and distance from canal $=0.375 \mathrm{U}$

Table 3: values of $\mathrm{Q}(\mathrm{cc} / \mathrm{sec})$ case (2)

\begin{tabular}{|l|l|}
\hline$\Delta \mathrm{H}=0.375 \mathrm{U}=15 \mathrm{~cm}$ & $\mathrm{Q}=140(\mathrm{cc} / \mathrm{min})$. \\
\hline$\Delta \mathrm{H}=0.625 \mathrm{U}=25 \mathrm{~cm}$ & $\mathrm{Q}=230(\mathrm{cc} / \mathrm{min})$. \\
\hline$\Delta \mathrm{H}=0.875 \mathrm{U}=35 \mathrm{~cm}$ & $\mathrm{Q}=320(\mathrm{cc} / \mathrm{min})$. \\
\hline
\end{tabular}




\subsection{Clay wall@ $X=0.375 \mathrm{U}=15 \mathrm{~cm}, \mathrm{Y}=1.125 \mathrm{U}=45 \mathrm{~cm}$.}

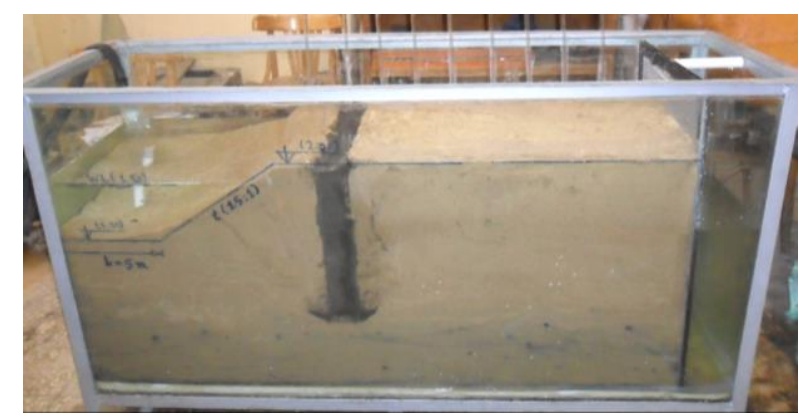

Figure 9: clay wall with depth $=1.125 \mathrm{U}$ and distance from canal $=0.375 \mathrm{U}$

Table 4: values of $\mathrm{Q}(\mathrm{cc} / \mathrm{sec})$ case (3)

\begin{tabular}{|l|l|}
\hline$\Delta \mathrm{H}=0.375 \mathrm{U}=15 \mathrm{~cm}$ & $\mathrm{Q}=125$ (cc/min.) \\
\hline$\Delta \mathrm{H}=0.625 \mathrm{U}=25 \mathrm{~cm}$ & $\mathrm{Q}=210$ (cc/min.) \\
\hline$\Delta \mathrm{H}=0.875 \mathrm{U}=35 \mathrm{~cm}$ & $\mathrm{Q}=310$ (cc/min.) \\
\hline
\end{tabular}

\subsection{Clay wall@ $X=0.375 \mathrm{U}=15 \mathrm{~cm}, Y=1.5 \mathrm{U}=60 \mathrm{~cm}$.}

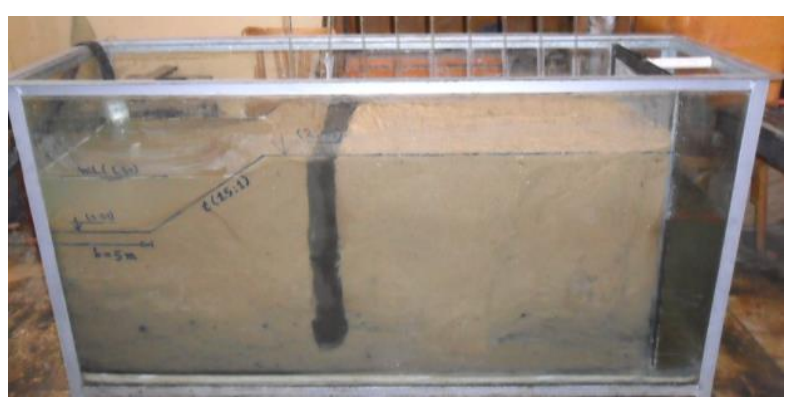

Figure 10: clay wall with depth $=1.5 \mathrm{U}$ and distance from canal $=0.375 \mathrm{U}$

Table 5: values of $\mathrm{Q}(\mathrm{cc} / \mathrm{sec})$ case (4)

\begin{tabular}{|l|l|}
\hline$\Delta \mathrm{H}=0.375 \mathrm{U}=15 \mathrm{~cm}$ & $\mathrm{Q}=105$ (cc/min.) \\
\hline$\Delta \mathrm{H}=0.625 \mathrm{U}=25 \mathrm{~cm}$ & $\mathrm{Q}=175$ (cc/min.) \\
\hline$\Delta \mathrm{H}=0.875 \mathrm{U}=35 \mathrm{~cm}$ & $\mathrm{Q}=275$ (cc/min.) \\
\hline
\end{tabular}

For $X=0.375 U=15 \mathrm{~cm}$, the following data has been obtained:

\begin{tabular}{|c|c|c|c|}
\hline & \multicolumn{3}{|c|}{$\mathrm{Q}$ (cc/min.) } \\
\hline $\mathrm{Y}(\mathrm{U})$ & $\Delta \mathrm{H}=0.375 \mathrm{U}$ & $\Delta \mathrm{H}=0.625 \mathrm{U}$ & $\Delta \mathrm{H}=0.875 \mathrm{U}$ \\
\hline 1.50 & 105 & 175 & 275 \\
1.125 & 125 & 210 & 310 \\
0.75 & 140 & 230 & 320 \\
0.375 & 155 & 237 & 325 \\
0.00 & 160 & 240 & 325 \\
\hline
\end{tabular}

The relation between [Q, Y (U)]are plotted in figure 11 for all the three cases of different $(\Delta \mathrm{H})$, and for $(\mathrm{X}=0.375 \mathrm{U})$

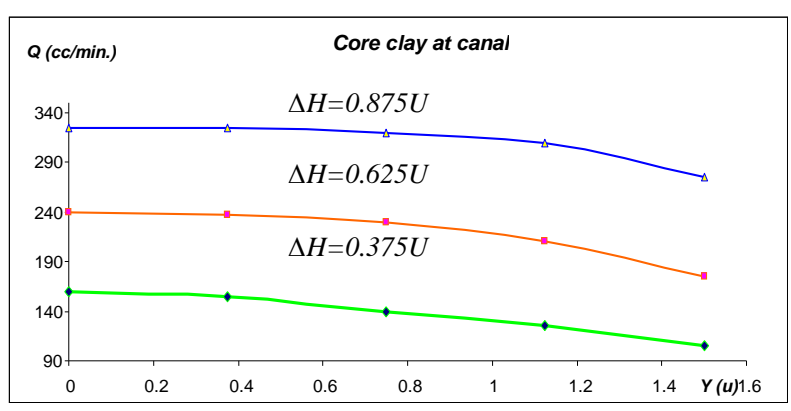

Figure (11)

\subsection{Clay wall@ $\mathrm{X}=1.125 \mathrm{U}=45 \mathrm{~cm}, \mathrm{Y}=0.375 \mathrm{U}=15 \mathrm{~cm}$.}

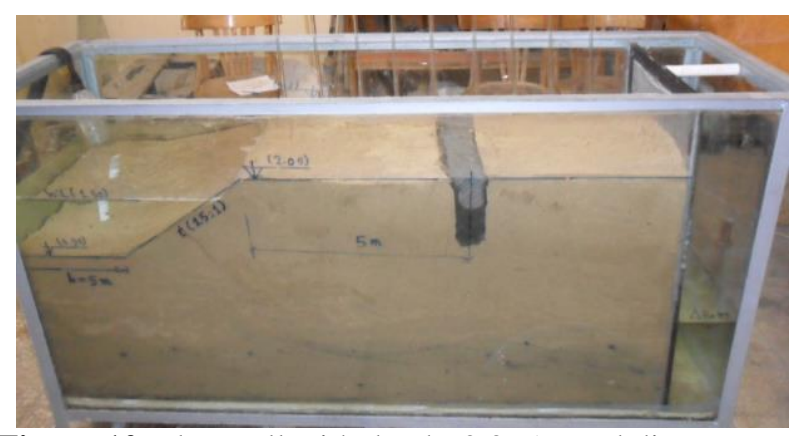

Figure 12: clay wall with depth $=0.375 \mathrm{U}$ and distance from canal $=1.125 \mathrm{U}$

Table 6: values of $\mathrm{Q}(\mathrm{cc} / \mathrm{sec})$ case (5)

\begin{tabular}{|l|l|}
\hline$\Delta \mathrm{H}=0.375 \mathrm{U}=15 \mathrm{~cm}$ & $\mathrm{Q}=157$ (cc/min.) \\
\hline$\Delta \mathrm{H}=0.625 \mathrm{U}=25 \mathrm{~cm}$ & $\mathrm{Q}=240(\mathrm{cc} / \mathrm{min})$. \\
\hline$\Delta \mathrm{H}=0.875 \mathrm{U}=35 \mathrm{~cm}$ & $\mathrm{Q}=325(\mathrm{cc} / \mathrm{min})$. \\
\hline
\end{tabular}

\subsection{Clay wall@ $\mathrm{X}=1.125 \mathrm{U}=45 \mathrm{~cm}, \mathrm{Y}=0.75 \mathrm{U}=30 \mathrm{~cm}$.}

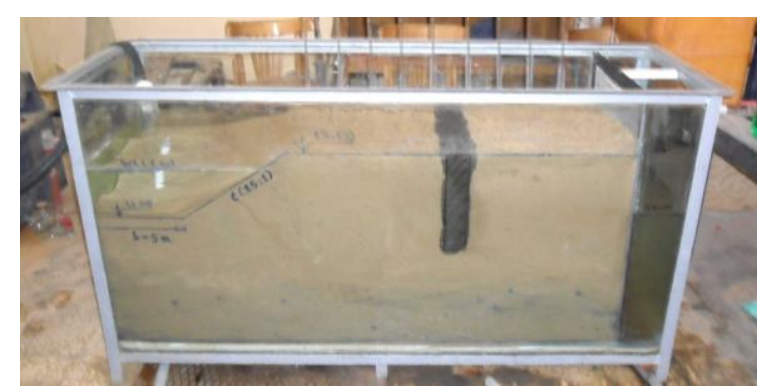

Figure 13: clay wall with depth $=0.75 \mathrm{U}$ and distance from canal $=1.125 \mathrm{U}$

Table 7: values of $\mathrm{Q}(\mathrm{cc} / \mathrm{sec})$ case (6)

\begin{tabular}{|l|l|}
\hline$\Delta \mathrm{H}=0.375 \mathrm{U}=15 \mathrm{~cm}$ & $\mathrm{Q}=147(\mathrm{cc} / \mathrm{min})$. \\
\hline$\Delta \mathrm{H}=0.625 \mathrm{U}=25 \mathrm{~cm}$ & $\mathrm{Q}=235(\mathrm{cc} / \mathrm{min})$. \\
\hline$\Delta \mathrm{H}=0.875 \mathrm{U}=35 \mathrm{~cm}$ & $\mathrm{Q}=320(\mathrm{cc} / \mathrm{min})$. \\
\hline
\end{tabular}


3.7 Clay wall@ X $=1.125 \mathrm{U}=45 \mathrm{~cm}, \mathrm{Y}=1.125 \mathrm{U}=45 \mathrm{~cm}$.

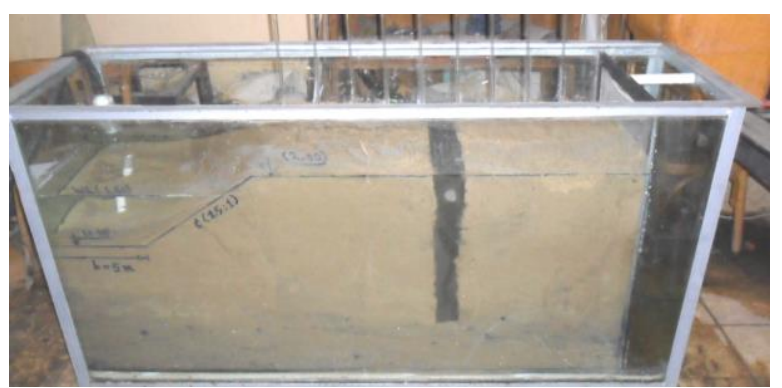

Figure 14: clay wall with depth $=1.125 \mathrm{U}$ and distance from canal $=1.125 \mathrm{U}$

Table 8: values of $\mathrm{Q}(\mathrm{cc} / \mathrm{sec})$ case (7)

\begin{tabular}{|l|l|}
\hline$\Delta \mathrm{H}=0.375 \mathrm{U}=15 \mathrm{~cm}$ & $\mathrm{Q}=130$ (cc/min.) \\
\hline$\Delta \mathrm{H}=0.625 \mathrm{U}=25 \mathrm{~cm}$ & $\mathrm{Q}=213$ (cc/min.) \\
\hline$\Delta \mathrm{H}=0.875 \mathrm{U}=35 \mathrm{~cm}$ & $\mathrm{Q}=315$ (cc/min.) \\
\hline
\end{tabular}

\subsection{Clay wall@ $X=1.125 \mathrm{U}=45 \mathrm{~cm}, \mathrm{Y}=1.5 \mathrm{U}=60 \mathrm{~cm}$.}

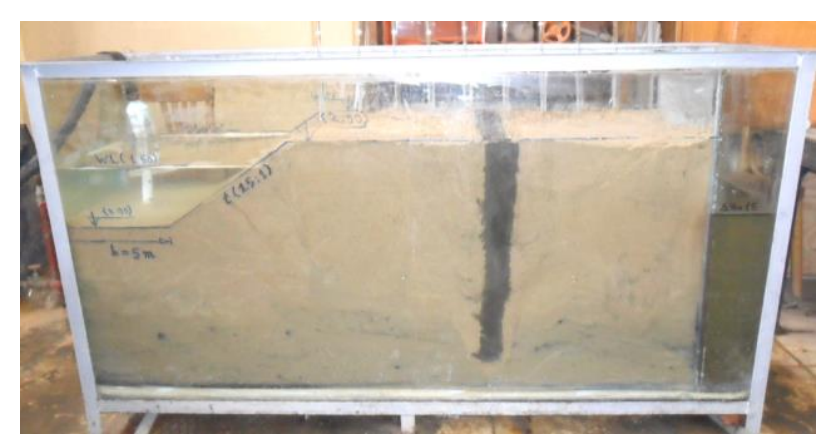

Figure 15: clay wall with depth $=1.5 \mathrm{U}$ and distance from canal $=1.125 \mathrm{U}$

Table 9: values of $\mathrm{Q}(\mathrm{cc} / \mathrm{sec})$ case (8)

\begin{tabular}{|c|l|}
\hline$\Delta \mathrm{H}=0.375 \mathrm{U}=15 \mathrm{~cm}$ & $\mathrm{Q}=110$ (cc/min.) \\
\hline$\Delta \mathrm{H}=0.625 \mathrm{U}=25 \mathrm{~cm}$ & $\mathrm{Q}=180(\mathrm{cc} / \mathrm{min})$. \\
\hline$\Delta \mathrm{H}=0.875 \mathrm{U}=35 \mathrm{~cm}$ & $\mathrm{Q}=280(\mathrm{cc} / \mathrm{min})$. \\
\hline
\end{tabular}

For $X=1.125 U=45 \mathrm{~cm}$, the following data has been obtained:

\begin{tabular}{|c|c|c|c|}
\hline & \multicolumn{3}{|c|}{$\mathrm{Q}$ (cc/min.) } \\
\hline $\mathrm{Y}(\mathrm{U})$ & $\Delta \mathrm{H}=0.375 \mathrm{U}$ & $\Delta \mathrm{H}=0.625 \mathrm{U}$ & $\Delta \mathrm{H}=0.875 \mathrm{U}$ \\
\hline 1.50 & 110 & 180 & 280 \\
1.125 & 130 & 213 & 315 \\
0.75 & 147 & 235 & 320 \\
0.375 & 157 & 240 & 325 \\
0.00 & 160 & 240 & 325 \\
\hline
\end{tabular}

The relation between [Q, Y (U)] are plotted in figure $\mathbf{1 6}$ for all the three cases of different $(\Delta \mathrm{H})$, and for $(\mathrm{X}=1.125 \mathrm{U})$

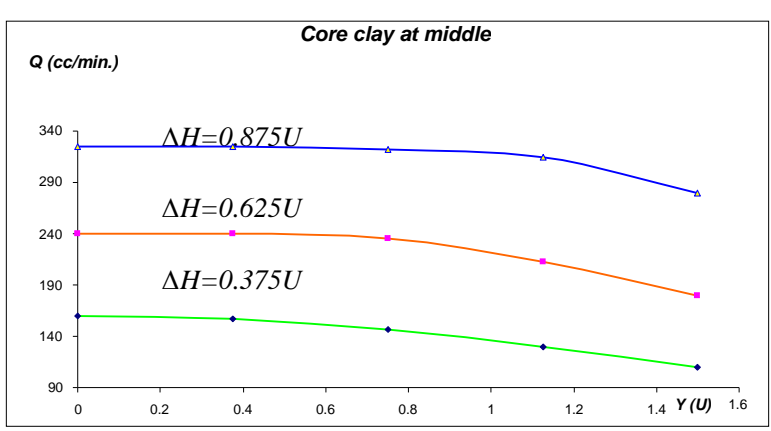

Figure (16)

\subsection{Clay wall@ $\mathrm{X}=1.875 \mathrm{U}=75 \mathrm{~cm}, \mathrm{Y}=0.375 \mathrm{U}=15 \mathrm{~cm}$.}

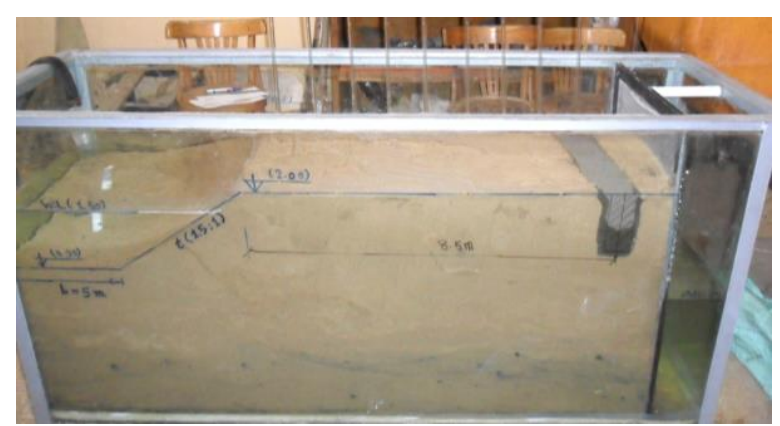

Figure 17: clay wall with depth $=0.375 \mathrm{U}$ and distance from canal $=1.875 \mathrm{U}$

Table 10: values of $Q(\mathrm{cc} / \mathrm{sec})$ case (9)

\begin{tabular}{|l|l|}
\hline$\Delta \mathrm{H}=0.375 \mathrm{U}=15 \mathrm{~cm}$ & $\mathrm{Q}=160(\mathrm{cc} / \mathrm{min})$. \\
\hline$\Delta \mathrm{H}=0.625 \mathrm{U}=25 \mathrm{~cm}$ & $\mathrm{Q}=240(\mathrm{cc} / \mathrm{min})$. \\
\hline$\Delta \mathrm{H}=0.875 \mathrm{U}=35 \mathrm{~cm}$ & $\mathrm{Q}=325(\mathrm{cc} / \mathrm{min})$. \\
\hline
\end{tabular}

\subsection{Clay wall@ $\mathrm{X}=1.875 \mathrm{U}=75 \mathrm{~cm}, \mathrm{Y}=0.75 \mathrm{U}=30 \mathrm{~cm}$.}

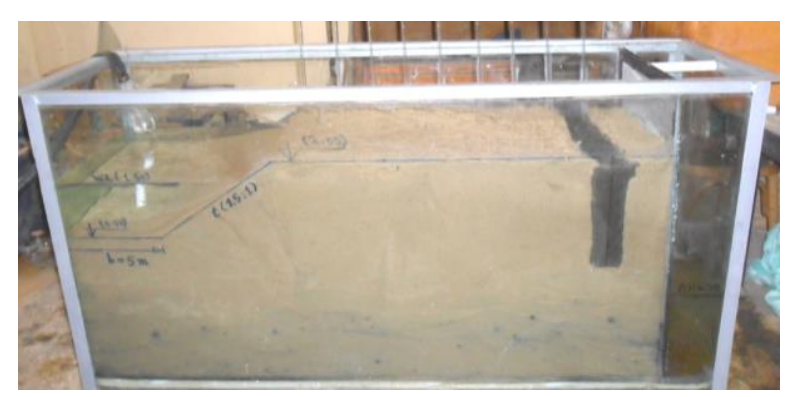

Figure 18: clay wall with depth $=0.75 \mathrm{U}$ and distance from canal $=1.875 \mathrm{U}$

Table 11: values of $Q(\mathrm{cc} / \mathrm{sec})$ case (10)

\begin{tabular}{|c|c|}
\hline$\Delta \mathrm{H}=0.375 \mathrm{U}=15 \mathrm{~cm}$ & $\mathrm{Q}=155$ (cc/min.) \\
\hline$\Delta \mathrm{H}=0.625 \mathrm{U}=25 \mathrm{~cm}$ & $\mathrm{Q}=237$ (cc/min.) \\
\hline$\Delta \mathrm{H}=0.875 \mathrm{U}=35 \mathrm{~cm}$ & $\mathrm{Q}=323(\mathrm{cc} / \mathrm{min})$. \\
\hline
\end{tabular}




\subsection{Clay wall@ $\mathrm{X}=1.875 \mathrm{U}=75 \mathrm{~cm}, \mathrm{Y}=1.125 \mathrm{U}=45 \mathrm{~cm}$.}

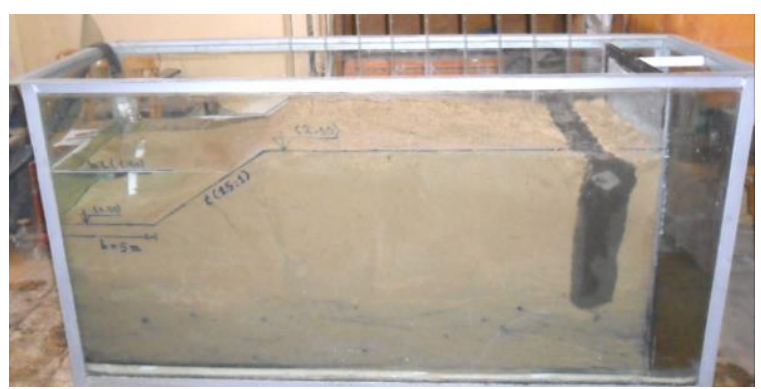

Figure 19: clay wall with depth $=1.125 \mathrm{U}$ and distance from canal $=1.875 \mathrm{U}$

Table 12: values of $Q$ (cc/sec) case (11)

\begin{tabular}{|c|l|}
\hline$\Delta \mathrm{H}=0.375 \mathrm{U}=15 \mathrm{~cm}$ & $\mathrm{Q}=143(\mathrm{cc} / \mathrm{min})$. \\
\hline$\Delta \mathrm{H}=0.625 \mathrm{U}=25 \mathrm{~cm}$ & $\mathrm{Q}=220(\mathrm{cc} / \mathrm{min})$. \\
\hline$\Delta \mathrm{H}=0.875 \mathrm{U}=35 \mathrm{~cm}$ & $\mathrm{Q}=317(\mathrm{cc} / \mathrm{min})$. \\
\hline
\end{tabular}

\subsection{Clay wall@ $\mathrm{X}=1.875 \mathrm{U}=75 \mathrm{~cm}, \mathrm{Y}=1.5 \mathrm{U}=60 \mathrm{~cm}$.}

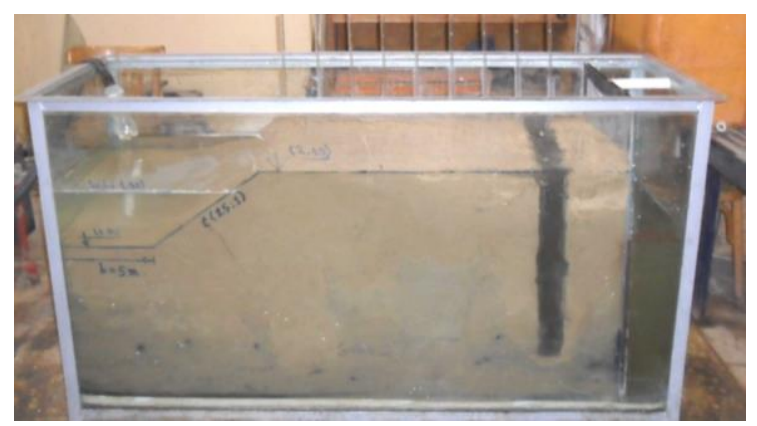

Figure 20: clay wall with depth $=1.5 \mathrm{U}$ and distance from canal $=1.875 \mathrm{U}$

Table 13: values of $Q$ (cc/sec) case (12)

\begin{tabular}{|c|c|}
\hline$\Delta \mathrm{H}=0.375 \mathrm{U}=15 \mathrm{~cm}$ & $\mathrm{Q}=115(\mathrm{cc} / \mathrm{min})$. \\
\hline$\Delta \mathrm{H}=0.625 \mathrm{U}=25 \mathrm{~cm}$ & $\mathrm{Q}=190(\mathrm{cc} / \mathrm{min})$. \\
\hline$\Delta \mathrm{H}=0.875 \mathrm{U}=35 \mathrm{~cm}$ & $\mathrm{Q}=285(\mathrm{cc} / \mathrm{min})$. \\
\hline
\end{tabular}

For $X=1.875 U=75 \mathrm{~cm}$, the following data has been obtained:

\begin{tabular}{|c|c|c|c|}
\hline & \multicolumn{3}{|c|}{$\mathrm{Q}$ (cc/min.) } \\
\hline $\mathrm{Y}(\mathrm{U})$ & $\Delta \mathrm{H}=0.375 \mathrm{U}$ & $\Delta \mathrm{H}=0.625 \mathrm{U}$ & $\Delta \mathrm{H}=0.875 \mathrm{U}$ \\
\hline 1.50 & 115 & 190 & 285 \\
1.125 & 143 & 220 & 317 \\
0.75 & 155 & 237 & 323 \\
0.375 & 160 & 240 & 325 \\
0.00 & 160 & 240 & 325 \\
\hline
\end{tabular}

The relation between [Q, Y (U)]are plotted in figure 21 for all the three cases of different $(\Delta \mathrm{H})$, and for $(\mathrm{X}=1.875 \mathrm{U})$

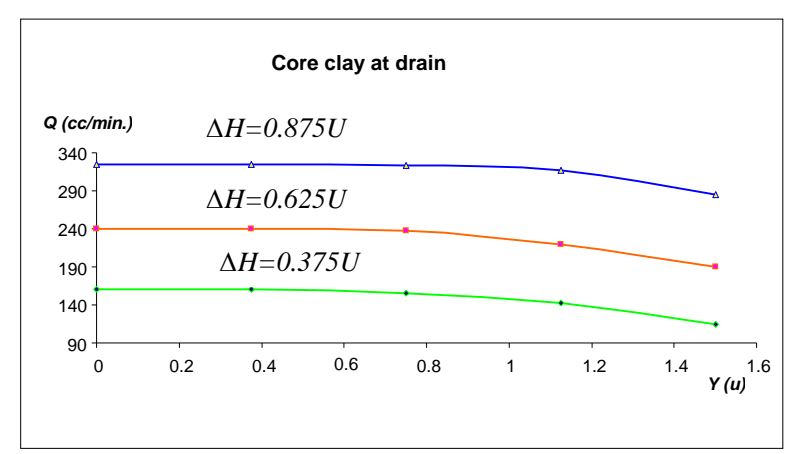

Figure (21)

For $\Delta \mathrm{H}=0.375 \mathrm{U}=15 \mathrm{~cm}$, which represents a shallow water table above channel bottom, a smooth curve has resulted and it could be seen that it has increased some how in linear manner as the depth of the clay wall decreased, the seepage quantity increases in relatively the same percentage, so the first conclusion of this case indicates that an application of the clay wall is efficient even though when the clay wall did not reach the impermeable layer.

For $\Delta \mathrm{H}=0.875 \mathrm{U}=35 \mathrm{~cm}$, which represents the case of deep water table below channel bottom behave in different manner. Because the vertical component of flow becomes more and more significant. This curve has increased sharply when the depth of the clay wall has decreased with small percentage. This situation indicates that the clay wall used to reduce seepage quantity is inefficient unless the clay wall has reached the impermeable layer.

Where as for $\Delta \mathrm{H}=0.625 \mathrm{U}=25 \mathrm{~cm}$, which represents a medium water table depth, show a behavior in between the two cases.

\section{EFFECT OF THE CLAY CORE POSITION ON SEEPAGE}

The clay wall has been placed at three different distances $(15,45,75 \mathrm{~cm})$ from canal and head difference $(\Delta \mathrm{H})$ is set to be $15 \mathrm{~cm}=0.375 \mathrm{U}$ and the depth of clay wall(Y) varied as before. The results are being tabulated as follows: 


\begin{tabular}{|c|c|c|c|}
\hline & \multicolumn{3}{|c|}{$\mathrm{Q}(\mathrm{cc} / \mathrm{min})$} \\
\hline $\mathrm{Y}(\mathrm{U})$ & $\mathrm{X}(\mathrm{U})=1.875$ & $\mathrm{X}(\mathrm{U})=1.125$ & $\mathrm{X}(\mathrm{U})=0.375$ \\
& & 110 & 105 \\
\hline 1.50 & 115 & 130 & 125 \\
1.125 & 143 & 147 & 140 \\
0.75 & 155 & 157 & 155 \\
0.375 & 160 & 160 & 160 \\
0.00 & 160 & & \\
& & &
\end{tabular}

The relation between [Q, Y (U)]are plotted in figure 22 for all the three cases of different distance $(\mathrm{X})$, and for $(\Delta \mathrm{H}=0.375 \mathrm{U})$

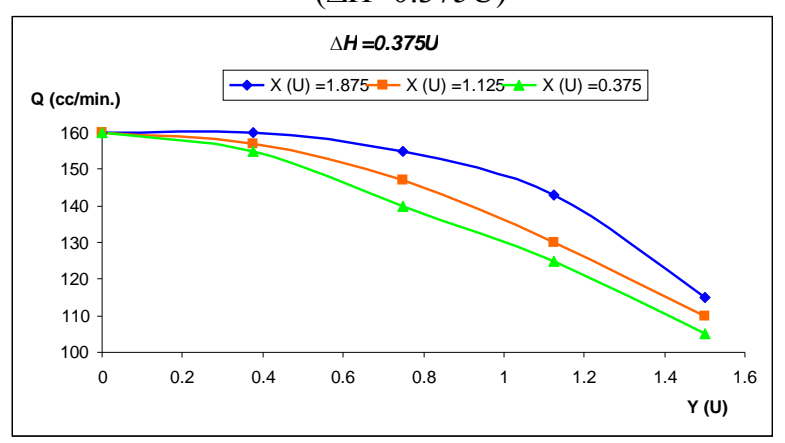

Figure (22)

The clay wall has been placed at three different distances $(15,45,75 \mathrm{~cm})$ from canal and head difference $(\Delta \mathrm{H})$ is set to be $25 \mathrm{~cm}=0.625 \mathrm{U}$ and the depth of clay wall(Y) varied as before. The results are being tabulated as follows:

\begin{tabular}{|c|c|c|c|}
\hline & \multicolumn{3}{|c|}{$\mathrm{Q}(\mathrm{cc} / \mathrm{min})$} \\
\hline $\mathrm{Y}(\mathrm{U})$ & $\mathrm{X}(\mathrm{U})=1.875$ & $\mathrm{X}(\mathrm{U})=1.125$ & $\mathrm{X}(\mathrm{U})=0.375$ \\
& & & \\
\hline 1.50 & 190 & 180 & 175 \\
1.125 & 220 & 213 & 210 \\
0.75 & 237 & 235 & 230 \\
0.375 & 240 & 240 & 237 \\
0.00 & 240 & 240 & 240 \\
& & & \\
\hline
\end{tabular}

The relation between [Q, Y (U)]are plotted in figure 23 for all the three cases of different $(\mathrm{X})$, and for $(\Delta \mathrm{H}=0.625 \mathrm{U})$

Figure (23)

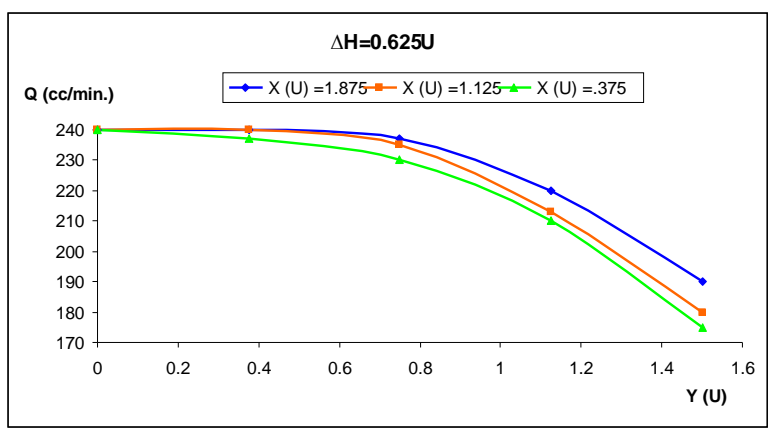

The clay wall has been placed at three different distances $(15,45,75 \mathrm{~cm})$ from canal and head difference $(\Delta \mathrm{H})$ is set to be $35 \mathrm{~cm}=0.875 \mathrm{U}$ and the depth of clay wall varied as before. The results are being tabulated as follows:

\begin{tabular}{|c|c|c|c|}
\hline & \multicolumn{3}{|c|}{$\mathrm{Q}(\mathrm{cc} / \mathrm{min})$} \\
\hline $\mathrm{Y}(\mathrm{U})$ & $\mathrm{X}(\mathrm{U})=1.875$ & $\mathrm{X}(\mathrm{U})=1.125$ & $\mathrm{X}(\mathrm{U})=0.375$ \\
& & 280 & 275 \\
\hline 1.50 & 285 & 315 & 310 \\
1.125 & 317 & 320 & 320 \\
0.75 & 323 & 325 & 325 \\
0.375 & 325 & 325 & 325 \\
0.00 & 325 & & \\
& & & \\
\hline
\end{tabular}

The relation between [Q, Y (U)]are plotted in figure $\mathbf{2 4}$ for all the three cases of different $(\mathrm{X})$, and for $(\Delta \mathrm{H}=0.875 \mathrm{U})$

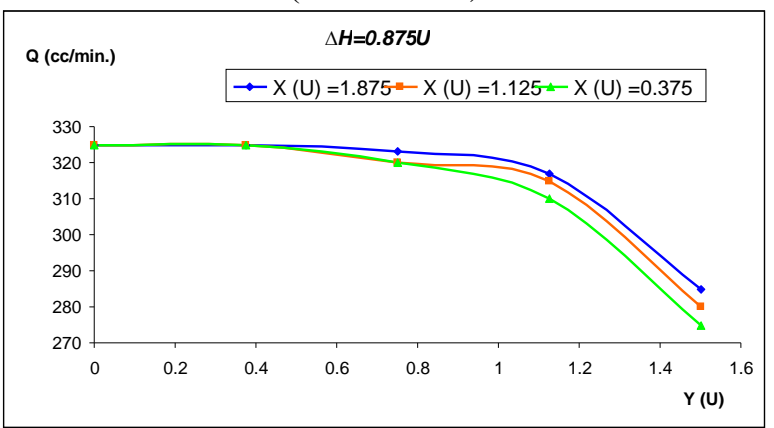

Figure (24)

It can be seen that the most efficient position of clay wall is at the closest distance to the channel center line, since the closest position increases the length of the seepage line compared to its length when the clay wall is placed farther from the center line of seepage.

The relation between [Reduction in $(\mathrm{Q}), \mathrm{Y}(\mathrm{U})]$ are plotted in figure 25 for all the three cases of different $(\mathrm{X})$, and for $(\Delta \mathrm{H}=0.375 \mathrm{U})$, results are being tabulated as follows:

\begin{tabular}{|c|c|c|c|}
\hline & \multicolumn{3}{|c|}{$\%$ Reduction Q(cc/min) } \\
\hline $\mathrm{Y}(\mathrm{U})$ & $\mathrm{X}(\mathrm{U})=1.875$ & $\mathrm{X}(\mathrm{U})=1.125$ & $\mathrm{X}(\mathrm{U})=0.375$ \\
& & & \\
\hline 1.50 & $28.13 \%$ & $31.25 \%$ & $34.38 \%$ \\
1.125 & $10.63 \%$ & $18.75 \%$ & $21.88 \%$ \\
0.75 & $3.13 \%$ & $8.13 \%$ & $12.50 \%$ \\
0.375 & $0.00 \%$ & $1.88 \%$ & $3.13 \%$ \\
0.00 & $0.00 \%$ & $0.00 \%$ & $0.00 \%$ \\
& & & \\
\hline
\end{tabular}

The relation between [Reduction in (Q), Y (U)] are plotted in figure $\mathbf{2 6}$ for all the three cases of different 
$(\mathrm{X})$, and for $(\Delta \mathrm{H}=0.625 \mathrm{U})$, results are being tabulated as follows:

\begin{tabular}{|c|c|c|c|}
\hline & \multicolumn{3}{|c|}{$\%$ Reduction $\mathrm{Q}(\mathrm{cc} / \mathrm{min})$} \\
\hline $\mathrm{Y}(\mathrm{U})$ & $\mathrm{X}(\mathrm{U})=1.875$ & $\mathrm{X}(\mathrm{U})=1.125$ & $\mathrm{X}(\mathrm{U})=0.375$ \\
& & $25.00 \%$ & $27.00 \%$ \\
\hline 1.50 & $20.83 \%$ & $11.25 \%$ & $12.50 \%$ \\
1.125 & $8.33 \%$ & $2.08 \%$ & $4.16 \%$ \\
0.75 & $1.25 \%$ & $0.00 \%$ & $1.25 \%$ \\
0.375 & $0.00 \%$ & $0.00 \%$ & $0.00 \%$ \\
0.00 & $0.00 \%$ & & \\
& & & \\
\hline
\end{tabular}

The relation between [Reduction in $(\mathrm{Q}), \mathrm{Y}(\mathrm{U})]$ are plotted in figure $\mathbf{2 7}$ for all the three cases of different $(\mathrm{X})$, and for $(\Delta \mathrm{H}=0.825 \mathrm{U})$, results are being tabulated as follows:

\begin{tabular}{|c|c|c|c|}
\hline & \multicolumn{3}{|c|}{$\%$ Reduction Q(cc/min) } \\
\hline $\mathrm{Y}(\mathrm{U})$ & $\mathrm{X}(\mathrm{U})=1.875$ & $\mathrm{X}(\mathrm{U})=1.125$ & $\mathrm{X}(\mathrm{U})=0.375$ \\
& & & \\
\hline 1.50 & $12.30 \%$ & $13.85 \%$ & $15.38 \%$ \\
1.125 & $2.46 \%$ & $3.07 \%$ & $4.62 \%$ \\
0.75 & $0.62 \%$ & $1.54 \%$ & $1.54 \%$ \\
0.375 & $0.00 \%$ & $0.00 \%$ & $0.00 \%$ \\
0.00 & $0.00 \%$ & $0.00 \%$ & $0.00 \%$ \\
& & & \\
\hline
\end{tabular}

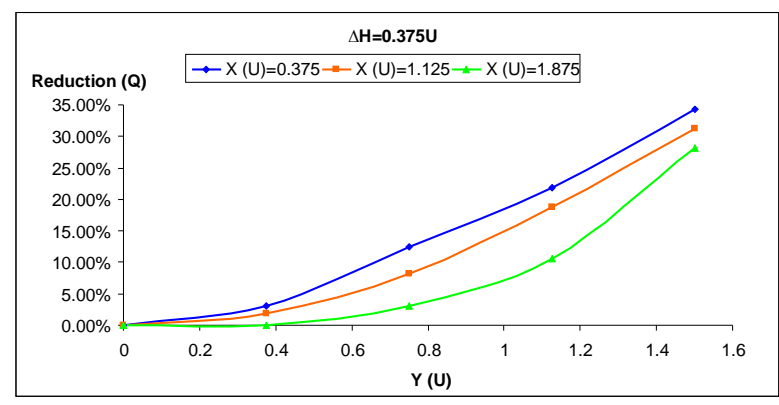

Figure (25)

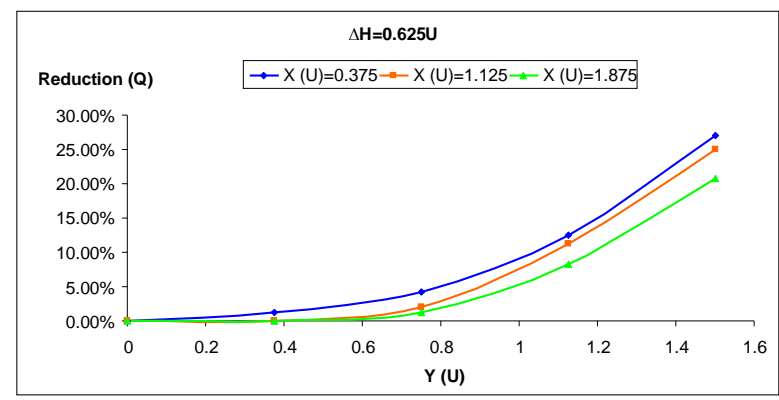

Figure (26)

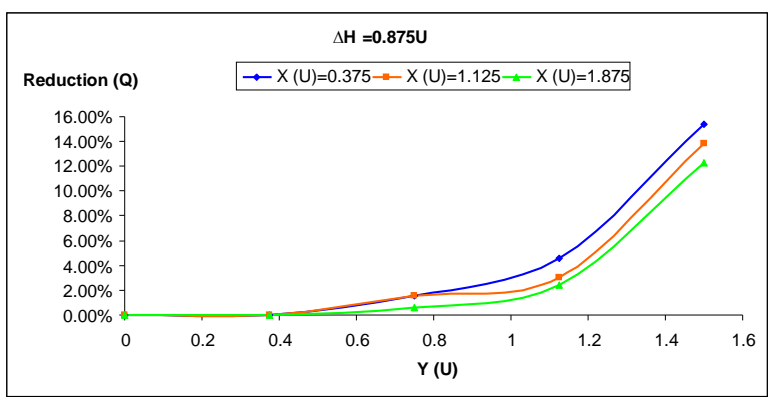

Figure (27)

\section{CONCLUSIONS}

The following points are the main concluded considerations.

1. It can be concluded that the closest clay core to the center of the canal, the seepage line is longer.

2. When $\Delta H$ is small the clay wall is effective so that the seepage quantity has decreased considerably.

3. It was found that the position of the clay wall is more effective near the channel; this is due to the fact that the creep length in contact of the clay wall is the largest.

4. The observation for $(\Delta \mathrm{H}=0.375 \mathrm{U}=15 \mathrm{~cm})$ which represents a shallow water table above channel bottom shows that the effect of the clay wall near the channel for $\mathrm{Y}>0.75 \mathrm{U}=30 \mathrm{~cm}$, the curve decreases very fast. This shows that the seepage rate will decrease largely as $\mathrm{Y}$ increases.

5. other conclusion, that the seepage rate was affected by many factors such as:

(5-1) Location of the clay wall.

(5-2) The head difference and the depth of water table.

(5-3) The depth of the clay wall in the ground.

*The clay wall cannot stop the seepage from the open channel to groundwater, but it decreases it.

\section{REFERENCES}

[1] Bouwer, H. "Groundwater hydrology", McGrawHill Kogakusha ltd.

[2] Craig, R. F. "Soil mechanics", $7^{\text {th }}$ edition.

[3] Bulter, S. "Engineering Hydrology", PrenticeHall, Inc.

[4] Harr, M. E. "Groundwater and seepage"

[5] Muskat, M. "Flow of homogeneous fluids through porous media", McGraw-Hill Book Co.

[6] Beer, j. 1979. "Hydraulics of groundwater" New York.

[7] Hansen, V. E. "Irrigation principle and practices". 
[8] Wenzel, L. K. "The Darcy law and it's relation to permeability", Methods of Determining Permeability of Water-Bearing Materials, WaterSupply paper 887.U. S. Geol. Survey, Washington, D. C.

[9] Benjamin T. Staud, "Seepage through longitudinal drainage trenches" Thesis, West Virginia University, Faculty of Engineering and Mineral Resources, Civil Engineering Department, (2000).

[10] Alaa Ahmed A., "Seepage and slope stability of large canals" Thesis, Zagazig University, Faculty of Engineering, Civil Engineering Department, (2009).

[11] Rawya M. Kansoh, "Effect of sheet piles position on seepage and erosion", International conference on protection and development of the Nile and other major rivers, Cairo, February 3-5, (1992).

[12] David K. TODD, "Laboratory research with ground water models", University of California, Berkeley, Civil Engineering Dep.

[13] Khalid Fadel Alsenousi and Hasan G. Mohamed, "Effect of inclined cutoffs and foundation characteristics on seepage beneath hydraulic structures", $12^{\text {th }}$ International Water technology Conference, Alexandria, Egypt (2008).

[14] Equipment for Engineering Education, Experiment Instruction, "HM 169Drainage and seepage Tank" 